\title{
Effect of technical indexes on cost-effectiveness in dairy farms participating in the "Balde Cheio" program at different stages of production
}

\section{Efeito de índices técnicos na rentabilidade de propriedades leiteiras participantes do programa "Balde Cheio" com diferentes escalas de produção}

\author{
Marcos Aurélio Lopes ${ }^{1 *}$; Flávio de Moraes $^{2}$; \\ Francisval de Melo Carvalho ${ }^{1}$; Afonso Aurélio de Carvalho Peres ${ }^{3}$; \\ Fabio Raphael Pascotti Bruhn'; Eduardo Mitke Brandão Reis ${ }^{5}$
}

\begin{abstract}
This study assesses the effects of technical and managerial indexes on the cost-effectiveness of 20 demonstration units (DUs) that participated in the "Full Bucket" ("Balde Cheio") program, at different stages of production, in the state of Rio de Janeiro, from January to December 2011. Here, costeffectiveness was assessed by considering gross margin, net margin, result (financial profit or loss), cost-effectiveness, and profitability as indicators of financial efficiency. Data were analyzed using PASW 18.0. A multiple linear regression model was used with the stepwise method to identify the managerial, technical, and other indexes that most affected profitability and cost-effectiveness. The production systems were categorized into three production levels: small (nine DUs), medium (nine DUs), or large (two DUs). The managerial and technical indexes differed according to the stages of production under study. The daily milk production for the three categories were below $151 \mathrm{~kg}, 151$ to $400 \mathrm{~kg}$, and above $400 \mathrm{~kg}$, respectively. The best profitability and cost-effectiveness at the large production level resulted from selling livestock. This level showed greater animal/day productivity (kg of milk), the best cows/farm manpower ratio, and the best number of herd animals/farm manpower ratio, whereas the medium level showed a lower fixed cost/total cost relation. The small production level showed the best percentages of lactating cows, cows in the herd, and lactating cows in the herd, as well as the best productivity/ha/year and lactating cows/ha. However, the latter results were not sufficient to generate a profit, owing to the small scale of production.
\end{abstract}

Key words: Dairy cattle. Economy. Management. Managerial indexes. Zootechnical indexes.

\section{Resumo}

Objetivou-se analisar o efeito de alguns índices técnicos e gerenciais na rentabilidade de 20 unidades demonstrativas (UD) com diferentes escalas de produção, participantes do programa "Balde Cheio", no estado do Rio de Janeiro, no período de janeiro a dezembro de 2011. Realizou-se a análise de rentabilidade

\footnotetext{
${ }^{1}$ Profs., Universidade Federal de Lavras, UFLA, Lavras, MG, Brasil. Bolsista do CNPq. E-mail: malopes@dmv.ufla.br; francarv@ dae.ufla.br

${ }^{2}$ M.e, Médico Veterinário Autônomo, UFLA, Lavras, Brasil. E-mail: f.demoraes2009@gmail.com

3 Prof., Universidade Federal Fluminense, UFF, Niterói, RJ, Brasil. E-mail: lelo@metal.eeimvr.uff.br

${ }^{4}$ Prof., Universidade Federal de Pelotas, UFPel, Pelotas, RS, Brasil. E-mail: fabio_rpb@yahoo.com.br

${ }_{5}$ Prof., Universidade Federal do Acre, UFAC, Rio Branco, AC, Doutorando em Ciências Veterinárias, UFLA, Lavras, Brasil. E-mail: edumitke@hotmail.com

* Author for correspondence
} 
considerando a margem bruta, a margem líquida, o resultado (lucro ou prejuízo), a rentabilidade e a lucratividade como indicadores de eficiência econômica. Os dados foram analisados utilizando-se o software PASW 18.0. Utilizou-se o modelo de regressão linear múltipla com o método stepwise, para identificar os índices técnicos e gerenciais que mais influenciaram na lucratividade e na rentabilidade. Os sistemas de produção foram alocados em um dos três estratos de produção: pequeno (nove), médio (nove) ou grande (dois), cujas produções diárias de leite foram inferiores a $151 \mathrm{~kg}$, de 151 a $400 \mathrm{~kg}$ e superiores a 400kg, respectivamente. Os índices técnicos e gerenciais foram diferentes nas escalas de produção estudadas e influenciaram na lucratividade e na rentabilidade. As melhores lucratividade e rentabilidade, do estrato grande, foram reflexos da venda de animais. Tal estrato apresentou melhor produtividade animal/dia ( $\mathrm{kg}$ de leite), melhor relação matrizes/mão de obra e a melhor relação de quantidade de animais do rebanho/mão de obra, enquanto que o estrato médio apresentou a menor relação custo fixo/custo total. $\mathrm{O}$ estrato pequeno apresentou as melhores porcentagens de vacas em lactação, vacas no rebanho, vacas em lactação no rebanho e as melhores produtividades/ha/ano e vacas em lactação/ha. No entanto, não foi suficiente para a obtenção do lucro, em virtude da pequena escala de produção.

Palavras-chave: Bovinocultura de leite. Economia. Gerenciamento. Índices zootécnicos e gerenciais.

\section{Introduction}

Many rural entrepreneurs do not manage their businesses with the promptness and efficiency required to be competitive in the market. Therefore, monitoring zootechnical and economic indexes may be a tool for better managing the technicaleconomic performance of dairy activities and for making planning decisions in the highly competitive environment faced by dairy farmers, which includes uncertainty and decreasing profit margins. The indexes reflect a farm's business situation in a particular period and identify possible bottlenecks that may affect its financial results. According to Tupy et al. (2003), once an inefficiency is quantified, the determining factors may be identified and financial losses can be prevented. In addition, an awareness of the financial efficiency of some herds may be valuable, and can be used as a reference by other farms.

The use of indexes to assess dairy farm efficiency is common among farmers and technical staff who manage farms. Lopes et al. (2004, 2005) calculated several managerial and technical indexes. According to Lopes et al. (2009), farming profitability may be assessed by technical indexes because these are related to production and, consequently, to a farmer's profits. Thus, breeders and farm technical staff should estimate indexes carefully, and then determine which indexes can be used to achieve cost-effective situations in order to identify bottlenecks, maximize production, and minimize costs.

Taking into account the great heterogeneity observed in the milk production chain in Brazil, its widespread presence, and the dynamic character of the dairy production environment, we need to stratify farmers based on the indexes they and the production systems achieve. Diverse criteria have been used to classify milk production systems, including their production levels.

The "Full Bucket" ("Balde Cheio") program was developed by the Southeast Cattle Research Center (CPPSE) of the Brazilian Agricultural Research Corporation (EMBRAPA) in São Carlos, SP. The program resulted from the need to support inefficient milk farms by training rural professionals and farmers, promoting the networking of information on technologies being applied regionally, and monitoring the environmental, economic, and social impact of the production systems (EMBRAPA, 2011).

Several researchers have examined the estimation of production costs and the economic viability of dairy farming (GODINHO; CARVALHO, 2009; SILVA et al., 2008; CARLOTTO et al., 2011; SILVEIRA et al., 2011; LOPES et al., 2011; LOPES et al., 2015). However, few studies have assessed 
the effect of managerial and technical indexes on cost-effectiveness. Considering the lack of research on this topic, the importance of the "Balde Cheio" program, and the impact of this topic in Brazil (particularly, the state of Rio de Janeiro), we study the effect of several managerial and technical indexes on cost-effectiveness in 20 demonstration units (DUs) that participated in the "Balde Cheio" program, at different stages of production.

\section{Materials and Methods}

The data analyzed were from 20 milk production systems, called demonstration units (DUs), that in 2011 participated in the "Balde Cheio" program, located in the state of Rio de Janeiro. The municipality of Natividade had two DUs, and the municipalities of Valença, Carmo, and Campos dos Goitacazes had three DUs. The municipalities of Quatis, Barra Mansa, Barra do Piraí, Paraíba do Sul, Santa Maria Madalena, Aperibé, Conceição de Macabu, Itaperuna, and Varre-Sai had just one DU each.

Non-probability sampling based on judgment was performed using the data provided by the technicians of the program, who were located at the different municipalities of the state of Rio de Janeiro. These data were recorded by farmers in a field notebook throughout the year, and collected at each monthly visit by the technician responsible for that DU.

In order to analyze the influence of the productionlevel factor on the managerial and technical indexes in milk production, the 20 production systems were assigned to one of three levels of production (small, medium, or large). The small, medium, and large levels had daily production of milk below $151 \mathrm{~kg}$, 151 to $400 \mathrm{~kg}$, and above $400 \mathrm{~kg}$, respectively, and are based on the work of Lopes et al. (2006). Nine DUs fell within the small production level, a further nine DUs fell within the medium level, and two DUs were classified as large production farms.
The following were used as cost-effectiveness factors: gross margin (revenue less effective operational cost), net margin (revenue less total operational cost) (MATSUNAGA et al., 1976) and result (revenue less total cost) (BARROS, 1948). Profitability $_{1}$ is estimated as the result divided by total revenue, multiplied by 100 (Profitability $_{1}(\%)$ $=$ Result $/$ Total revenue $\times 100$ ). Cost-effectiveness ${ }_{1}$ is the result divided by the sum of total fixed assets and effective operational costs, multiplied by 100 (Cost-effectiveness $_{1}(\%)=$ Result/(Total fixed assets + Effective operational cost) $\times 100)($ SEBRAE, 1998). Profitability ${ }_{2}$ is the net margin divided by total revenue, multiplied by 100 (Profitability $_{2}(\%)=$ Net margin/Total revenue $\times 100$ ). Cost-effectiveness ${ }_{2}$ is the net margin divided by the sum of total fixed assets and the effective operational cost, multiplied by 100 (Cost-effectiveness ${ }_{2}(\%)=$ Net margin/ (Total fixed assets + Effective operational cost) $\times$ 100) (LOPES et al., 2011).

For the statistical analysis, the production and economical indexes were initially registered in a database in Microsoft Excel ${ }^{\circledR}$, to subsequently export them to the statistical software PASW 18.0. The Shapiro-Wilk normality test was performed, and the Levene homogeneity of variance test was performed to evaluate the distribution of the continuous variables. Here, we observed that some did not present a normal distribution and/ or homoscedasticity. The latter variables were expressed using the median and the interquartile difference, whereas those variables that presented a normal distribution and/or homoscedasticity were described using the average \pm standard deviation. An ANOVA test was used to compare the dependent variables (economic, technical, and managerial) among the categories of independent variables (production levels), complemented by the Bonferroni correction test for multiple comparisons. When data did not present a normal distribution and/or variance equality, the comparisons between groups were performed using the Kruskal-Wallis test, complemented by the LSD test for multiple 
comparisons between the ranked variable averages (MAROCO, 2010). The difference was considered statistically different when $\mathrm{P}<0.05$.

\section{Results and Discussion}

Table 1 shows the managerial and technical indexes grouped according to the production levels of the 20 DUs that participated in the "Balde Cheio" program from January to December 2011 in the state of Rio de Janeiro. Table 2 depicts a summary of the cost-effectiveness analysis. The relations between cows and the number of herd animals per manpower were higher in the large DUs than they were in the medium DUs, which, in turn, were higher than those in the small DUs. The small-scale production farms were different from those in the other two categories ( $\mathrm{P}<0.05)$. Lopes et al. (2008a) observed that the values for a small farm were below 14.40 cows/manpower, whereas the medium and large levels had values above 15.87 and above 13.07 cows/manpower, respectively.

The percentage of lactating cows, cows in the herd, and lactating cows in the herd were similar $(\mathrm{P}>0.05)$ between levels. This was because all DUs participated in the same technical assistance program (see Table 1). Sousa et al. (2011) found that $50.00 \%$ of cows in herds were lactating, while Lopes et al. (2010) found this value to be $58.40 \%$. According to these authors, this fact influenced the low number of cows per production area. In contrast, a better reproduction efficiency was observed in the DUs of the present study, in which approximately $83.30 \%$ of cows were lactating, considered by the FAEMG (2006) guidelines to be ideal.

With regard to daily animal productivity, the large production level was, numerically, the best; however, it was not statistically different $(\mathrm{P}>0.05)$ to the other levels. Lopes et al. (2008a) found a daily animal productivity lower than 15.95 in large farms.

The values for the productivity animal/ha/year (Table 1) were similar $(\mathrm{P}>0.05)$ among the levels, and higher than those found by Lopes et al. (2008a), which were 2,954.38, 2,282.36, and 2,435.61 for small, medium, and large levels, respectively. The values were also higher than those of FAEMG (2006), which were $1,188.5 \mathrm{~kg} / \mathrm{ha} /$ year. A high standard deviation was found for small DUs. This was because one of the DUs had a production of $71,126.00 \mathrm{~kg}$ of milk and 13.3 cows in lactation/ha. Such values had not previously been reported in the literature. The lower productivity/ha/year observed in the large DUs was due to their greater farm area.

With regard to the number of cows in lactation per area, the levels were similar $(\mathrm{P}>0.05)$ (see Table 1). Lopes et al. (2008a) found these values to be $0.82,0.22$, and 0.43 for the small, medium, and large levels of production, respectively. In contrast, Lopes et al. (2010) found that the farms had an average of 1.39 , and minimum and maximum values of 0.26 and 3.5, respectively. Fassio et al. (2006) found 1.34 AU/ha.

The data on productivity and capacity per area illustrate that the DUs that were assisted by the "Balde Cheio" program were more efficient in using their land. This information is of utmost importance, because it may affect the implementation of public policies targeting family farmers. These policies would increase farmers' income and dignity and, consequently, their self-esteem. As a result, more people would settle in rural areas, thus reducing rural depopulation.

The total and operational equilibrium points were statistically different $(\mathrm{P}<0.05)$ among levels (Table 1). The fixed asset value of machines and equipment, not compatible with the production level, was responsible for the total and operational equilibrium points being higher than the daily milk production. However, a positive result was observed for the medium and large levels.

With regard to the family manpower/total operating cost (TOC) relation (Table 1 ), the medium and large levels were similar $(\mathrm{P}>0.05)$ because the manpower of both family and mixed types were 
observed at these levels. At the small production level, the manpower mainly comprised the family.

The effective operating cost (EOC)/TOC ratio (Table 1) showed a difference $(\mathrm{P}<0.05)$ between small farms and the remaining farms, which were similar $(P>0.05)$. This may be justified by the fact that family manpower was highly represented in the TOC of small farms, which reduces the proportional contribution of EOC in the TOC.

When only the selling of dairy milk was considered (Table 2), negative values were observed, showing how important the sale of animals is to revenue. The values observed in this study showed that many managerial and technological efforts should aim at increasing average variable costs, which, in turn, would increase the total and operational equilibrium points. This is in agreement with the findings of Lopes et al. (2008a). According to the authors, an alternative is to increase production efficiency, that is, productivity per cow, therefore optimizing manpower, drugs, artificial insemination, fixed taxes, energy, and other diverse expenses. Such expenses are not improved by increasing the productivity per cow.

In this study, the representativeness of fixed expenses in the total cost was similar among production levels, which was not expected, because the costs become diluted as the volume of milk produced and the number of animals increase. In other studies, the fixed expenses were greater than $24.10 \%$ of the total cost (LOPES et al., 2011), greater than $16.08 \%$ (ALMEIDA JÚNIOR et al., 2002), and approximately the same value of $27.20 \%$ (LOPES et al., 2008b). These results show that the investments in all the levels were sized to a dairy milk production greater than the average found in literature. This statement fits mainly a DU (50.00\%) from the large farms, because it has a total asset value above average. In that $\mathrm{DU}$, the $\mathrm{CF} / \mathrm{CT}$ ratio was $33.01 \%$. According to Lopes and Carvalho (2000), if the sale of goods does not occur and taxes do no increase, the fixed costs remain constant, regardless of the amount of milk produced. In order for the fixed costs to be representative of total costs, both production and productivity should be increased, reaching an economy of scale.

We observed that the small production level had a financial loss of $-\mathrm{R} \$ 2,844.06$, but had an asset increment in animals of $\mathrm{R} \$ 2,133.33$. Without analyzing any other asset increment, we may consider the financial loss to be $\mathrm{R} \$ 710.73$ $(-\mathrm{R} \$ 2,844.06+\mathrm{R} \$ 2,133.33)$.

The best profitability and cost-effectiveness at the large level resulted from selling animals. The small level showed better percentages of lactating cows, cows in the herd, lactating cows in the herd, and the best productivity/ha/year and lactating cows/ha. However, this was not enough to obtain a profit owing to the small scale of production. 


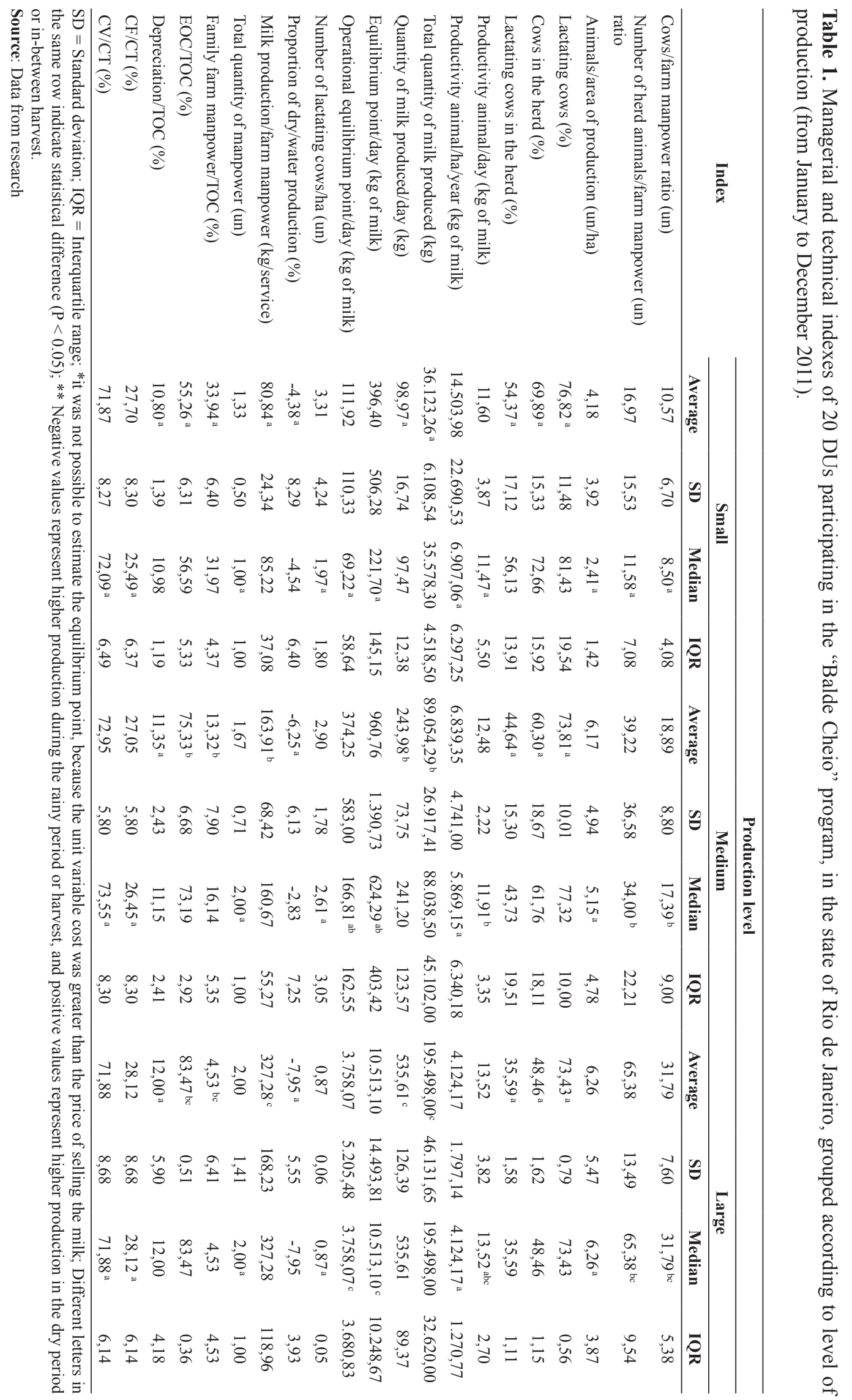



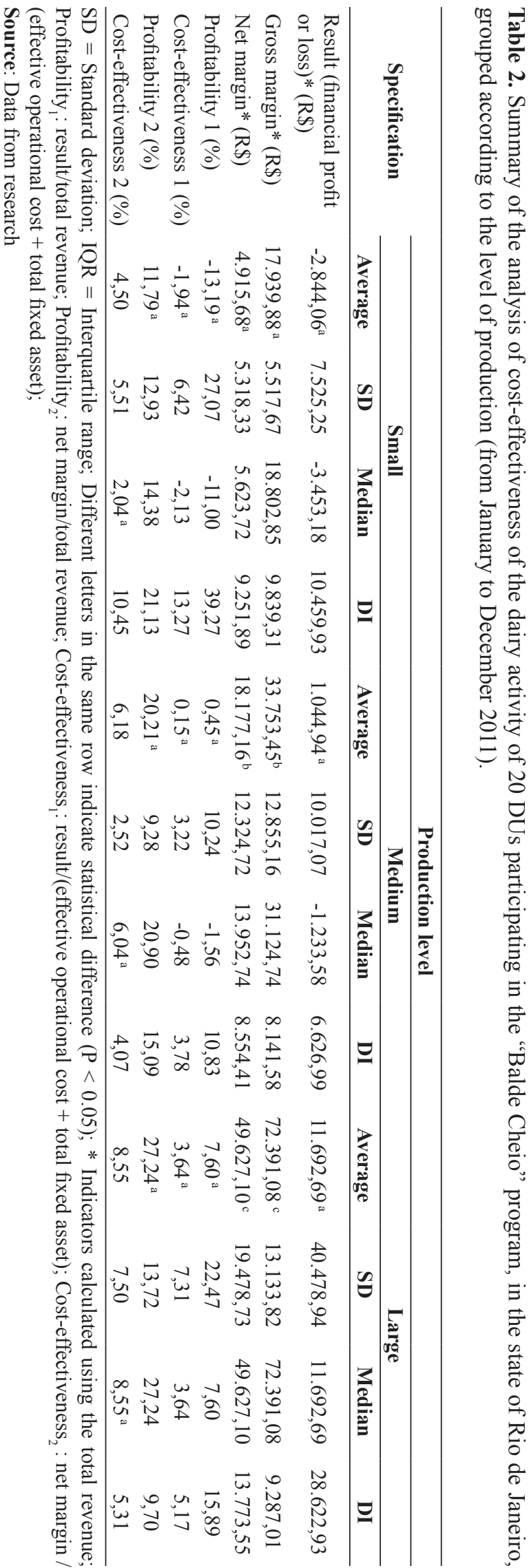

\section{Conclusions}

The managerial and technical indexes influenced the profitability and cost-effectiveness of the production levels.

The large level of production showed better productivity animal/day ( $\mathrm{kg}$ of milk), better cows/ manpower ratios, and a better number of herd animals/manpower ratio. The best profitability and cost-effectiveness were the result of selling animals.

The small level showed the best percentages of lactating cows, cows in the herd, and lactating cows in the herd, and the best productivity/ha/ year and lactating cows/ha. However, this was not enough to obtain a profit owing to the small scale of production.

The medium level showed the lowest fixed cost/ total cost ratio.

\section{References}

ALMEIDA JÚNIOR, G. A.; LOPES, M. A.; PINATTO, F. Efeito da venda de animais na rentabilidade de um sistema Intensivo de produção de leite tipo B no estado de São Paulo. In: REUNIÃO ANUAL DA SOCIEDADE BRASILEIRA DE ZOOTECNIA, 39., 2002, Recife. Anais... Recife: SBZ, 2002. p. 4-7.

BARROS, H. Economia agrária. 2. ed. Lisboa: Livraria Sá da Costa, 1948. 348 p.

CARLOTTO, I.; FILIPPI, J. A.; MARCELLO, I. E. Estudo da viabilidade da produção de leite em uma propriedade familiar rural do município de Francisco Beltrão - PR. Revista de Ciências Empresariais. UNIPAR, Umuarama, v. 12, n. 1, p. 95-109, 2011.

EMPRESA BRASILEIRA DE PESQUISA AGROPECUÁRIA - EMBRAPA. Projeto Balde Cheio. São Carlos: CPPSE, 2011. Disponível em: $<$ http://www. cppse.embrapa.br/balde-cheio $>$. Acesso em: 14 nov. 2015.

FASSIO, L. H.; REIS, R. P.; GERALDO, L. G. Desempenho técnico e econômico da atividade leiteira em Minas Gerais. Ciência e Agrotecnologia, Lavras, v. 30, n. 6, p. 1154-1161, 2006.

FEDERAÇÃO DA AGRICULTURA, PECUÁRIA E PESCA DO ESTADO DE MINAS GERAIS - FAEMG. Diagnóstico da pecuária leiteira do Estado de Minas 
Gerais em 2005. SEBRAE-MG, OCEMG e SENAR-AR/ MG. Belo Horizonte: FAEMG, 2006. 156 p

GODINHO, R. F.; CARVALHO, R. C. R. Gestão de sistemas de produção de leite. Ciência et Praxis, Passos, v. 2, n. 3, p. 77-89, 2009.

LOPES, A. D.; OLIVEIRA, M. D. S.; FONSECA, M. I. Características técnicas das propriedades de baixa escala leiteira observadas na área de abrangência do escritório de desenvolvimento rural de Jaboticabal - SP. Revista Ciência em Extensão, São Paulo, v. 6, n. 2, p. 32-45, 2010.

LOPES, M. A.; CARDOSO, M. G.; CARVALHO, F. M.; LIMA, A. L. R.; DIAS, A. S.; CARMO, E. A. Resultados econômicos da atividade leiteira na região de Lavras (MG) nos anos 2004 e 2005: um estudo multicasos. Arquivo Brasileiro de Medicina Veterinária e Zootecnia, Belo Horizonte, v. 60, n. 2, p. 428-435, 2008 b.

LOPES, M. A.; CARVALHO, F. M. Custo de produção do leite. Lavras: FAEPE, 2000. 42 p. (Boletim Agropecuário, 32).

LOPES, M. A.; DIAS, A. S.; CARVALHO, F. M.; LIMA, A. L. R.; CARDOSO, M. G.; CARMO, E. A. Efeito da escala de produção nos resultados econômicos de sistemas de produção de leite na região de Lavras ( $\mathrm{MG}$, Brasil), em 2004 e 2005. Archivo Latinoamericano de Producción Animal, Maracaibo, v. 16, n. 3, p. 129-137, 2008a.

Resultados econômicos de sistemas de produção de leite com diferentes níveis tecnológicos na região de Lavras, MG nos anos 2004 e 2005. Ciência e Agrotecnologia, Lavras, v. 33, n. 1, p. 252-260, 2009.

LOPES, M. A.; LIMA, A. L. R.; CARVALHO, F. M.; REIS, R. P.; SANTOS, I. C.; SARAIVA, F. H. Controle gerencial e estudo da rentabilidade de sistemas de produção de leite na região de Lavras, MG. Ciência e Agrotecnologia, Lavras, v. 28, n. 4, p. 883-892, 2004.

Efeito da escala de produção nos resultados econômicos de sistemas de produção de leite na região de Lavras (MG): um estudo multicasos. Boletim de Indústria Animal, Nova Odessa, v. 63, n. 3, p. 177-188, 2006.

Resultados econômicos de sistemas de produção de leite com diferentes níveis tecnológicos na região de Lavras, MG. Arquivo Brasileiro de Medicina Veterinária e Zootecnia, Belo Horizonte, v. 57, n. 4, p. 485-493, 2005.
LOPES, M. A.; MORAES, F.; CARVALHO, F. M.; PERES, A. A. C.; BRUHN, F. R. P.; REIS, E. M. B. The effect of technological levels on profits of milk production systems participating in the full bucket program: a multicase study. Semina: Ciências Agrárias, Londrina, v. 36, n. 4, p. 2909-2922, 2015.

LOPES, M. A.; SANTOS, G.; RESENDE, M. C.; CARVAlHO, F. M.; CARDOSO, M. G. Estudo da rentabilidade de sistemas de produção de leite no município de Nazareno, MG. Revista Ciência Animal Brasileira, Goiânia, v. 12, n. 1, p. 58-69, 2011.

MAROCO, J. Análise estatística com utilização do SPSS. 3. ed. Lisboa: Sílabo, 2010. 822 p.

MATSUNAGA, M.; BEMELMANS, P. F.; TOLEDO, P. E. N. Metodologia de custo de produção utilizado pelo IEA. Agricultura em São Paulo, São Paulo, v. 23, n. 1, p. 123-139, 1976.

SERVIÇO BRASILEIRO DE APOIO ÀS MICRO E PEQUENAS EMPRESAS - SEBRAE. Curso de capacitação rural. Goiânia: Editora Sebrae (GO), 1998. $34 \mathrm{p}$.

SILVA, H. A.; KOEHLER, H. S.; MORAES, A.; GUIMARÃES, V. A.; HACK, E.; CARVALHO, P. C. F. Análise da viabilidade econômica da produção de leite a pasto e com suplementos na região dos Campos GeraisParaná. Ciência Rural, Santa Maria, v. 38, n.2, p. 445450, 2008.

SILVEIRA, B. I. D.; PETERS, M. D. P.; STORCH, T.; ZIGUER, E. A.; FISCHER, V. Simulação da rentabilidade e viabilidade econômica de um modelo de produção de leite em free-stall. Arquivo Brasileiro de Medicina Veterinária e Zootecnia, Belo Horizonte, v. 63, n. 2, p. 392-398, 2011.

SOUSA, M. R. P.; RISTOW, A. M.; NOGUEIRA, E. B.; TORRES FILHO, R. A.; CORTEZ, M. A. S. Caracterização de pequenas unidades produtoras de leite na região centro e noroeste do estado do Rio de Janeiro. Revista Brasileira de Medicina Veterinária, Niterói, v. 18, n. 2-3, p. 79-84, 2011.

TUPY, O.; FREITAS, A. D.; ESTEVES, S. N.; SCHIFFLER, E.; VIEIRA, M. C. Eficiência econômica na produção de leite tipo B no estado de São Paulo. Informações Econômicas, São Paulo, v. 33, n. 10, p. 1420, 2003. 